\title{
MŰVÉSZET ÉS TÁRSADALOMTUDOMÁNY EGYÜTTMÜKÖDÉSE A POSZTNORMÁL TUDOMÁNYFELFOGÁS KERETEIN BELÜL: BACKCASTING KUTATÁSI EREDMÉNYEK EGY INTERAKTÍV SZÍNHÁZI KALANDJÁTÉKBAN
}

\section{THE CO-OPERATION OF ART AND SOCIAL SCIENCES IN THE SPIRIT OF POSTNORMAL SCIENCE: THE RESULTS OF A BACKCASTING RESEARCH IN AN INTERACTIVE THEATRE ADVENTURE GAME}

\author{
Köves Alexandra ${ }^{1,4}$, Gáspár Judit ${ }^{2,4}$, Matolay Réka ${ }^{3,4}$ \\ ${ }^{1} \mathrm{PhD}$, egyetemi adjunktus \\ alexandra.koves@uni-corvinus.hu \\ ${ }^{2} \mathrm{PhD}$, egyetemi adjunktus \\ judit.gaspar@uni-corvinus.hu \\ ${ }^{3} \mathrm{PhD}$, egyetemi docens \\ reka.matolay@uni-corvinus.hu \\ Budapesti Corvinus Egyetem Vállalatgazdaságtan Intézet Döntéselmélet Tanszék, Budapest
}

\section{ÖSSZEFOGLALÁS}

A posztnormál tudomány felfogása mentén kutató társadalomtudósok folyamatosan keresik azokat a megoldásokat, amelyek egyrészt a társadalom különböző szereplőinek megértésével, másrészt bevonásával, harmadrészt pedig széles körű elérésével tudnak feltárni társadalmi összefüggéseket és lehetséges megoldásokat a hozzájuk kötődő problémákra. Szintén céljuk a problémák felderítése kapcsán olyan társadalmi változások elindítása, amelyek kívánatosnak tartott irányokba vezetnek. Jelen cikk egy olyan együttmüködés tapasztalatait mutatja be a társadalomtudomány és a művészetek között, amely a posztnormál tudományfelfogás alapján képes elmélyíteni az adott problémáról kialakult megértésünket, feltárni a lehetséges megoldások természetrajzát, valamint elérni egy szélesebb közönséget, annak érdekében, hogy a szükséges változások elindulhassanak. Az eredeti kutatás a fordított jövőkutatási módszert, a backcastingot hívta segítségül annak kiderítésére, hogy hogyan működhetnének fenntarthatóan és felelősen a gazdasági szereplők. Míg a backcasting kutatás eredményei önmagukban is érdekesek, a hagyományos tudományos publikációkon túl a kutatók azt is szerették volna látni, hogy mit tudnak egy színtársulat tagjai kezdeni a nyers adatokkal, és a létrejövő "nagyközönség" számára is érthetővé tett kutatás milyen hatást érhet el. A kísérletből végül a Tünet Együttes interaktív színházi kalandjátéka jött létre, ahol a kutatás eredményeit az alkotók értelmezték, lefordították, és egy elgondolkodtató művészeti élménnyé alakították. Az együttműködés tapasztalatainak tudományos szintű feldolgozása és bemutatása bepillantást nyújthat abba, hogy milyen lehetőségek rejlenek a színház és a társadalomtudományi kutatások öszszefogásában. 


\section{ABSTRACT}

Social scientists doing research within post-normal science are constantly on the look-out for solutions how to involve different actors in society to deepen the understanding of social issues and find possible solutions. They also aim to initiate social transformations that lead towards desirable answers to current problems. This article presents the experiences of a post-normal collaboration between social science and arts that deepened our understanding of a given problem, explored the nature of possible solutions, and reached a wider audience in order to bring about the necessary change. The original research used the method of backcasting to find out how economic operators could operate more sustainably and responsibly. While results of the backcasting research may alone be interesting, the researchers wanted to move beyond traditional scientific publications. They wanted to see what a theatre company can do with the raw data and how the results of that research would be received by the general public. The experiment eventually evolved into the Symptom Ensemble's interactive theatrical adventure game, where the research results were interpreted, translated and transformed into a thought-provoking art experience. The scientific processing and presentation of such a collaborative experience provides an insight into the potential of cooperation between theatre and social science research.

Kulcsszavak: kutatásalapú művészet, múvészetalapú kutatás, backcasting, fenntartható vállalatok, posztnormál tudomány

Keywords: research-based-art, art-based-research, backcasting, sustainable businesses, post-normal science

\section{BEVEZETÉS}

A posztnormál tudomány felfogása mentén kutató társadalomtudósok folyamatosan keresik azokat a megoldásokat, amelyek a társadalom különböző szereplőinek megértésével bevonásával és széles körủ elérésével tudnak feltárni társadalmi összefüggéseket és lehetséges megoldásokat a hozzájuk kötődő problémákra. Szintén céljuk a problémák felderítése kapcsán olyan társadalmi változások elindítása, amelyek kívánatosnak tartott irányokba vezetnek. A normál tudománnyal szemben a posztnormál tudomány már nemcsak verifikálni kívánja a valóságról felállított hipotéziseit, hanem - a tudományos hitelesség keretében maradva - a valóság mint társadalmi konstrukció megértöjévé és alakítójává is válik (Frame-Brown, 2008). Az 1990-es években népszerúvé váló, Silvio O. Funtowicz és Jerome R. Ravecz (1993) által megfogalmazott tudományfelfogás annak folyományaként jött létre, hogy a szerzők szerint a normál tudomány már egyre nehezebben nyújt hasznosítható tudást a mindinkább komplexszé váló, rosszul strukturált társadalmi-gazdasági-ökológiai „makacs problémák” (wicked problems) (Rittel-Weber, 1973) megoldásában. 
Jelen cikk egy olyan együttmüködés tapasztalatait mutatja be a társadalomtudomány és a müvészetek között, amely a posztnormál tudományfelfogás alapján képes elmélyíteni az adott problémáról kialakult megértésünket, feltárni a lehetséges ,"̈̈gyetlen megoldások” (clumsy solutions) (Shapiro, 1988) természetrajzát, valamint elérni egy szélesebb közönséget annak érdekében, hogy a szükséges változások elindulhassanak. Az eredeti kutatás a fordított jövőkutatási módszer, a backcasting (Köves, 2016) segítségét hívta annak kiderítésére, hogy hogyan müködhetnének fenntarthatóan és felelősen a gazdasági szereplők. A részvételi kutatásban cégvezetők, kutatók, fenntarthatósági szakértők és aktivisták arra keresték a normatív választ, hogy milyen vállalati struktúra, kultúra és milyen körülmények között funkcionálnának valóban felelősen és fenntarthatóan a cégek egy ideális jövőben, és ehhez milyen beavatkozások mentén, milyen úton lehetne végighaladni.

Míg a backcasting kutatás eredményei önmagukban is érdekesek lehetnek, a hagyományos tudományos publikációkon túl a kutatók azt is szerették volna látni, hogy mit tudnak egy színtársulat tagjai kezdeni a nyers adatokkal, és a „nagyközönség” számára is érthetővé tett kutatás milyen hatást érhet el. A Tünet Együttessel szorosan együttmüködő The Symptoms_Lab kísérleti egység célja, hogy interakción nyugvó formák létrehozásával közelebb vigyék a színházat az emberekhez. Ebböl született a TAG. A TAG (Theater Adventure Game) a pointand-click típusú számítógépes játékok alapján létrehozott, több helyszínen játszódó, interaktív színházi kalandjáték. A résztvevők kis létszámú csoportokban, a szereplőkkel és a környezetükkel kapcsolatba lépve haladnak elöre a cselekményben a megoldás felé, miközben ők maguk is történet részévé válnak.

Egy ilyen interaktív színházi kalandjáték jött létre a kutatók és az alkotók együttmúködéséből, ahol a kutatás eredményeit az alkotók értelmezték, lefordították, és egy elgondolkodtató müvészeti élménnyé alakították. A kalandjátékot 2018. július 12-én és 13-án mutatták be a Bánkitó Fesztiválon. A Jövő és Tsa. a résztvevőket egy megálmodott rendhagyó időutazás során 2058 ideális vállalati világába kalauzolta el. Maga a kutatási folyamat már önmagában is azt szolgálta, hogy feltárja a szükséges változások feltételeit, és később ez a társadalmi tanulás a közönség bevonásával a színdarabbal szélesebb körben is megvalósult. Az együttmüködés tapasztalatai bepillantást nyújthatnak abba, hogy milyen lehetöségek rejlenek a színház és a társadalomtudományi kutatások összefogásában.

Cikkünkben elöször röviden kitérünk a posztnormál tudományfelfogás alapgondolataira, annak érdekében, hogy az együttműködést keretbe helyezzük. A második fejezetben bemutatjuk az eredeti backcasting kutatást, és az ahhoz kötődő színházi kalandjáték létrejöttének folyamatát. A harmadik fejezetben a tudomány és a múvészet együttmúködésének módszertani keretein belül helyezzük el a magyar példát, majd a következtetések rész kitér annak értékelésére és az ahhoz kapcsolódó reflexiókra. 


\section{POSZTNORMÁL TUDOMÁNY}

A tudomány és a társadalom átalakult kapcsolatát, a kutatók és az állampolgárok a tudomány múvelésében megváltozott szerepét firtatja a posztnormál tudománykép, az ökológiai közgazdaságtan bázisa. Funtowicz és Ravetz, a közelítésmód első megfogalmazói úgy jellemzik környezetünket, hogy ,,a tények bizonytalanok, az értékek vitatottak, a tét nagy és a döntések sürgetők" (Funtowicz-Ravecz, 1993, 744.). A tudománynak összetett és makacs problémákra kell választ keresnie, és ez nem történhet transzdiszciplinaritás nélkül, valamint az úgynevezett kiterjesztett véleményező közösség, azaz a kutatókon túl az érintettek részvétele híján. A jelen egymással összekapcsolódó gazdasági, társadalmi és ökológiai problémáit nem normál tudományból egy frissebb normál tudományba lépéssel, hanem a tudományágak közötti ,hathatós párbeszéd és együttmüködés révén van esélyünk” megérteni és megoldani (Pataki-Takács-Sánta, 2004, 21.). A posztnormál tudományfelfogás ,természeténél fogva összetett rendszerekben (helyi közösségekben és azok akár globális hálózataiban) vizsgál összetett problémákat" (Réti-Varga, 2008, 7.). Így azt e szerzők a fenntarthatóságra nevelés egyik alapkoncepciójaként ajánlják.

A posztnormál szakít a kutatói objektivitás és értéksemlegesség szükségességével. Söt, azt hangsúlyozza, hogy „minden kutatást befolyásolnak értékek” (Ravetz, 2015, 3.). Következésképpen a kutató explicit értékválasztását szorgalmazza abban, amit és ahogyan kutat. Ennek mutatja be izgalmas reflexióit Kelemen Eszter (2016) a posztnormál alapokon nyugvó részvételi kutatások iránti személyes kutatói elkötelezettségéról és a kutatói tanulásról, valamint a kutató és nem kutató szakértőkről. A nem kutatói szakértők tehát azok, akik nem tudományos, ám mégis alapvetően fontos tudások birtokában vannak, legyen az laikus tapasztalat, hétköznapi heurisztikus tudás, szakmai ismeret, helyi tudás, egyéb szakértelem (lásd például Matolay, 2013). A kiterjesztett véleményező közösség túlmegy az akadémiai közeg és a kutatás forrásait nyújtók táborán. Ravetz a tudományos probléma - rendszerint közügy - valamennyi érintettjét ideérti, és egy posztnormál szellemben jól megkonstruált kutatás esetében e résztvevők, köztük a kutatók kölcsönös tanulását vetíti előre (Ravetz, 2015). Ebből a szempontból mind az alkotói folyamatban részt vevő müvészek, mind a darabra vagy annak társadalmi témáira reagáló nézők ilyen szakértőknek minősülnek a posztnormál tudományfelfogás bázisán.

\section{JÖVŐ ÉS TSA.: SZÍNHÁZI KALANDJÁTÉK A FELELŐS ÉS FENNTARTHATÓ VÁLLALATOKRÓL}

Napjaink környezeti és társadalmi problémáinak jelentős részét a jelenlegi gazdasági múködésünk generálja (Sekulova et al., 2013). Számos olyan kutatási irányzat létezik, amely arra a problémára keresi a választ, hogy hogyan lehet a gazdasági növekedésre épülő neoklasszikus közgazdasági modelleket és alapve- 
téseket meghaladni, annak érdekében, hogy egy környezetileg fenntarthatóbb és társadalmilag igazságosabb rendszert hozhassunk létre. Ilyen például az ökológiai közgazdaságtan (Røpke, 2004), amely feltételezi, hogy bármilyen elmozdulás egy alternatív irányba megköveteli azt, hogy képesek legyünk olyan konkrét beavatkozásokat javasolni, amelyek fel tudják oldani a jelenlegi rendszerek útfüggőségeit és bezáródó hatásait.

Annak kérdésköre, hogy hogyan müködhetnének a gazdasági szereplök a mostaninál jóval felelősebb és fenntarthatóbb formában minden ilyen megoldáskeresés központi eleme. Ennek a kérdésnek a vizsgálatáról szóló kutatás három szervezet (Budapesti Corvinus Egyetem, a Magyarországi Üzleti Tanács a Fenntartható Fejlődésért és a Civil Licit Alapítvány) önkéntes együttmüködéséből jött létre 2016-ban (Köves et al., 2019). A kutatáshoz a backcasting módszertant választottuk, egy olyan normatív szcenáriófejlesztési módszert, amely lehetővé teszi ideális jövőképek tervezését mind az egyének, mind a tágabb társadalmi intézmények esetében. A vízió felépítése után a módszer úgy tér vissza a jelenhez, hogy a résztvevők visszafelé haladva határozzák meg, hogy mit lehet tenni annak érdekében, hogy a kívánt állapot felé mozduljunk el. A backcasting módszer három legfontosabb jellemzője, amelyek miatt jól illeszkedik a fenntarthatósági kérdésekhez az, hogy a) komplex környezetet feltételez; b) olyan helyzetekben érdemes használni, amikor a jelenlegi trendek elfogadhatatlan eredményekhez vezetnek; és c) az emberekre aktív cselekvőként tekint a jövő átalakításában (Robinson, 2003).

A kétnapos kutatómunka során a tizenkét résztvevő a vállalati, civil és tudományos szférából arra kereste a választ, hogy „Milyen lesz a jövő cége? - Fenntartható és felelős gazdasági szereplők 2050-ben”. Először létrehoztak egy jövőképet, majd kidolgozták a szükséges lépéseket a jövőből a jelenig. Ebben az elképzelt jövőben a gazdasági szervezetek ,ügyközpontúak”, azaz alapvető céljaikat és kompetenciájukat egy társadalmi, közösségi vagy ökológiai probléma megoldása köré építik fel. A haszonmaximalizálás önmagában nem cél. Nyereség továbbra is létezik, ez azonban csak az értékteremtés mutatója az adott ügy megoldásában, és nem a felhalmozást szolgálja. A vállalati és a civil szektorok konvergenciája a résztvevők által elnevezett és továbbgondolt ún. „cuvée szervezeteket” eredményez. A gazdaság szoros közösségekre épül, és a társadalomban folyamatos társadalmi párbeszéd van az ügyekhez fontos értékekről és problémákról. A gazdasági szervezetek maguk is a demokrácia helyszínei mind a belső, mind a külső érintettek számára, akik valóban részt vesznek mind a stratégiai döntéshozatalban, mind a jövőtervezésben. A résztvevők által a visszafejtett lépések meghatározására kiválasztott főbb témák a következők voltak: 1) a cuvée szervezet attribútumai; 2) az ügy-profit viszony jellemzői: 3) az állam szerepe; 4) önszabályozó mechanizmusok, amelyek megakadályozzák a hatalmi központok létrejöttét; 5) az érintettek és az egyén felelőssége; és 6) a munka jövője. A mühelymunka után 
rendelkezésre álló adatok alapján a kutatók létrehoztak egy rendszertérképet (Király et al., 2014) annak érdekében, hogy a vízió és a különböző lépések mögötti legfontosabb tényezők dinamikus kölcsönhatását azonosítani tudják.

Miután a kutatókat a tudományos közzétételen túlmenően - a posztnormál tudományfelfogáshoz hủen - a társadalmi változásokhoz történő hozzájárulás is érdekelte, egy szokatlan partnerség lehetősége felé fordultak. A müvészet-tudomány együttmüködésével kapcsolatban leginkább arra keresték a választ, hogy 1) hogyan tudják a művészek könnyebben befogadható és egy szélesebb közönség számára is vonzó formátumra átfordítani a kutatási eredményeket; 2) hogyan generálhat ez aktivitást a közönség oldaláról; 3) hogyan járul hozzá az eredmények müvészek általi értelmezése a téma mélyebb megértéséhez; és 4) általában hogyan müködhet a mủvészet és a tudomány ilyen irányú együttmüködése. A színházi kalandjáték formátuma alkalmasnak tủnt a kutatás feldolgozásához, így az együttmüködés a Tünet Együttessel jött létre.

Először a müvészek megismerkedtek a kutatók azon szokatlan kérésével, hogy a mủvészet valamely formájára fordítsák le az eredeti kutatás mögött rejlö összefüggéseket. Miután számos különböző formátumot átgondoltak, úgy döntöttek, hogy a TAG logikája jól illeszkedik magának a kezdeményezésnek a céljaihoz, nevezetesen ahhoz, hogy az embereket az aktív szerepvállalásra ösztönözze a jelenlegi társadalmi és gazdasági intézmények megváltoztatásában. A backcasting mögött álló alapfeltételezés is az, hogy az emberek aktív alakítói a társadalmi folyamatoknak, és az események nem az ő döntéseiktől és értékvállalásaiktól függetlenül zajlanak a világban. Jól müködő analógiaként a TAG szintén megköveteli, hogy az emberek elhagyják a „passzív néző” kényelmes állapotát, és aktív résztvevői legyenek a cselekményeknek.

Miután a formátumban megegyeztek, az alkotók oly módon értelmezték, fordították le és alakították át a kutatási eredményeket, hogy azok egy müvészeti élmény alapját képezhessék. Annak érdekében, hogy ezt a transzformációs folyamatot kutatási szemmel is vizsgálhassák, a kutatók megpróbáltak a lehető legkisebb mértékben belefolyni az értelmezésekbe. Ez azonban kifejezetten nehéz vállalásnak bizonyult, mivel a fogalmak leginkább a közgazdaságtani szakmai nyelvezetet és logikát tükrözték, és így sokszor mélyebb magyarázatra szorultak. Ezért nehezen volt kivitelezhetö, hogy a közös nyelv megteremtéséig a kutatók kivonuljanak a folyamatból, és nyilvánvalóan a magyarázataikkal és példáikkal volt hatásuk az alkotókra. Ennek ellenére kimondható, hogy a megszületett alkotás a mủvészek és a kutatók közötti iteráció eredménye. A kutatók és az alkotók között történő megbeszéléseket rögzítették, így lehetőség nyílt arra, hogy esetleg további kutatást lehessen végezni magának az együttmüködés és a közös értelemadás felderítése céljából.

A létrejött Jövő és Tsa. előadás olyan emberek csoportjáról szól (maga a közönség), akik vállalnak egy jövőutazást, amikor azonban kilépnek az időgépből, rá- 
jönnek, hogy elhagyták a beszállókártyájukat, és így nem tudnak visszatérni a jelenbe. Ezért évtizedenként kell visszatérniük, hogy végül megtalálják a párkákat, akik képesek visszavezetni öket a jelenbe. Utazásukhoz egy vízgyártó vállalat vezetőinek személyazonosságát vállalják magukra, és a visszavezető évtizedek különböző helyzetekbe sodorják őket, ahol megtapasztalják a felelös üzleti döntések részleteit: a szellemi - minden érintett érdekeit figyelembe vevő - vezetést 2048-ban; nyereségük kötelező visszaforgatását társadalmilag fontos ügyekbe 2038-ban; és az átláthatóság megteremtését 2028-ban. A kalandjáték felépítését a backcasting módszere ihlette, míg maga a tartalom a müvészek által leginkább elgondolkodtatónak tartott kutatási eredményekből származik.

A színházi kalandjátékot először a Bánkitó Fesztiválon mutatták be 2018 júliusában, majd 2019 januárjában a Budapesti Corvinus Egyetemen (CUB). 2019 áprilisában az Európa Pont adott helyet egy újabb színpadra vitelnek. A TAG történetének megfelelően a különböző terek átalakultak: Bánkon a jeleneteket a polgármesteri hivatal elött és a templomkertben rendezték nyáron, természetes környezetben; míg az egyetemen a müvészeknek kreatívan kellett az oktatásra berendezett modern termeket a különbözö jelenetek megfelelő kellékeivé átalakítaniuk. Az Európa Pontban különböző funkciókra használt szobákban kellett több emeleten kialakítani ugyanezt. Különbség a közönségben is volt: Bánkon jókedvü fesztiválozó fiatalok, az egyetemen közgazdasági ismeretekkel rendelkező egyetemi oktatók, míg az Európa Pontban nagyon vegyes korú komolyabb érdeklődők vettek részt. Önmagában is izgalmas tapasztalat volt, hogy hogyan működött a kalandjáték a különböző környezetekben, és ezek hogyan inspirálták a résztvevőket.

A történetben a jelenbe történő visszalépést segítő „párkák” szerepét két kutató játszotta, akik akkor „engedték” vissza az utazókat a jelenbe, ha megosztják gondolataikat és kérdéseiket a kalandjáték által felvetett témákkal kapcsolatban. Így egyrészt sikerült bevonni a közönséget egy társadalmi párbeszédbe, másrészt értékes információkat gyüjthettek arról, hogy az emberek hogyan érezték magukat ezekben a vállalati helyzetekben, milyennek látták az alternatív jövőt; és hogyan tapasztalták meg az inaktivitás vagy épp tehetetlenség kényelmetlenségét magában a játékban vagy a valós életben.

\section{TUDOMÁNY ÉS MŰVÉSZET EGYÜTTMŪKÖDÉSEINEK MÓDSZERTANI ALAPJAI}

A tudomány és mủvészet együttmüködésének kutatási folyamatba ágyazott lehetöségeit mutatjuk be saját példánkon keresztül. A müvészetalapú kutatás során (art-based-research, ABR) a mủvészet, a színház is a kutatás módszerévé válik; illetve a kutatásalapú müvészet (research-based-art, RBA) irányzaton belül a kutatásalapú színház megközelítést követjük, ahol a dramatikus formák és a színház 
eszköztárának alkalmazásával az volt a célunk, hogy megmutassuk a kutatás során összegyüjtött tudást (Leavy, 2015).

Kutatóként egy kutatási jelentésben általában publikációban, adatokkal igazoltan mutatjuk be a kutatásaink eredményét (1. ábra - A folyamat). A müvészeti alkotás „alapanyagává” elsősorban azzal a szándékkal tettük kutatási eredményeinket, hogy felismeréseink és üzeneteink több emberhez érjenek el, és egy elgondolkodtató és bevonó közegben, szokatlan térben nagyobb hatással legyenek rájuk (1. ábra - B1, B2 folyamat). Így újabb dimenziók nyíltak meg a kutatás eredményeinek értelmezésében. (Fontos megjegyezni, hogy a kutatási folyamat során, illetve magának a kutatásnak lezárásakor nem volt direkt és előre eltervezett célunk az eredmények színpadra vitele.)

A müvészet felé fordulás a mi esetünkben már a kutatási folyamat lezárása után történt. A színészek és a rendező elolvasták a kutatási dokumentációnkat; a résztvevők által alkotott víziót és az eredményeket összefoglaló rendszertérképet, és közös beszélgetéseink, értelmezési folyamataink után alkották meg a színházi kalandjátékot (1. ábra-B1, B2 folyamat).

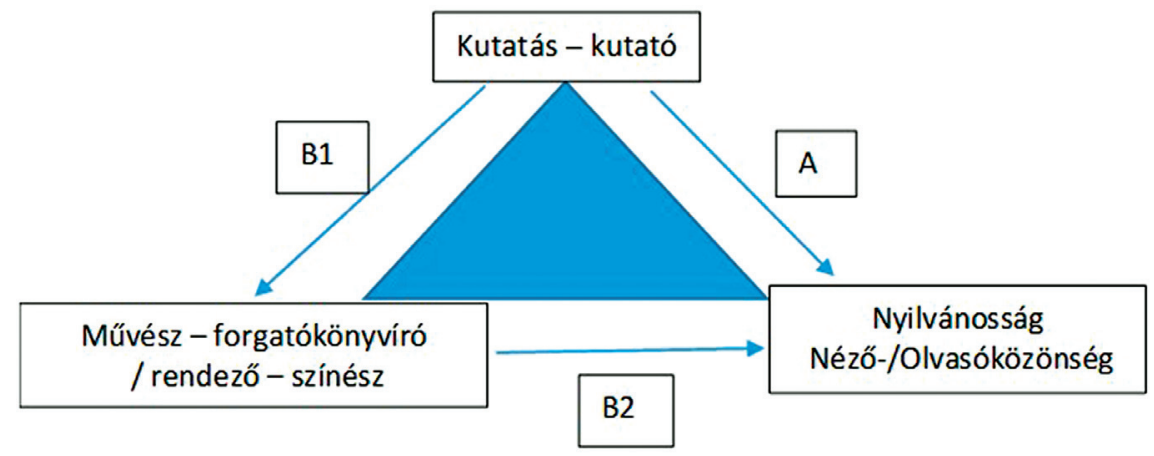

1. ábra. Kutatási eredmények útja a közönséghez (saját szerkesztés)

A kutató etikai felelősségét a színészek, az alkotók müvészi felelőssége váltotta fel, a múvészek az adatok és az esztétikai élmény között navigáltak, s követve a kutatásalapú színház elveit (1. táblázat), igyekeztek hủek maradni az adatokban rejlö lényeghez, miközben tisztelettel és alázattal elégítették ki a kutatói és a müvészeti igényeket.

A dokumentumok, adatok, a kutatási eredmény miképp válik egy múvészeti alkotás forrásává? A forgatókönyvírás folyamata teremti meg a hidat kutatási eredmény és müvészeti alkotás között. Az író - a kutatási dokumentumok olvasása és a kutatókkal történő beszélgetések során - teremti meg azt az értelmezési teret, színmüvet, melyben a kutatás elemei felvillannak. Visszatérő kérdés és dilemma 
a tudomány és mủvészet kapcsolatából, a dokumentumokhoz, az adatokhoz való hủség, illetve az alkotói szabadság és autonómia kérdése (Belliveau-Lea, 2016). A színházi eszköztár (dramaturgia, látványtervezés, forma és helyszín) segítségével ragadja meg a kutatásban rejlő tudást. Megnyitja a teret a nézők katarzisélményéhez, meghívást ad a katartikus válaszokra, a megérintődésre. Az érzelmekre, érzékekre hatva empátiát ébreszt, míg az adatok és az esztétikai élmény igénye között egyensúlyoz.

1. táblázat. A kutató és a művész eltérő szerepdefiníciói, céljai, felelőssége

\begin{tabular}{|l|l|l|}
\hline \multicolumn{1}{|c|}{ A kutató... / A múvész... } & \multicolumn{1}{|c|}{$\begin{array}{c}\text { A-papíralapú } \\
\text { kutatási beszámoló }\end{array}$} & \multicolumn{1}{|c|}{$\begin{array}{c}\text { B - kutatásalapú } \\
\text { színház, színjáték }\end{array}$} \\
\hline - célja a kutatás eredményeinek & elmesélése & megmutatása \\
- felelőssége & etikai & mủvészi/esztétikai \\
- elmélet & megalapozott (grounded) & megalapozatlan (groundless) \\
\hline
\end{tabular}

Saját szerkesztés Belliveau-Lea, 2016 alapján

Miképp jön létre színházi alkotás a kutatási eredményekből? A szövegkönyv/ forgatókönyv kialakulásának és a színpadkép, a dráma megteremtődésének folyamatát három típusba sorolják Graham W. Lea (2012) alapján. Létezik egy úgynevezett (1) „kollektív” megközelítés; ahol írók, rendezők, színészek közösen alkotják meg, és a próbafolyamat során improvizációknak is teret adva hozzák létre az alkotást, melynek jellemzője az eltérő nézőpontokat integráló megközelítés és a közös fejlesztési folyamat. Az ,íróközpontú” irányzat (2) a kutatói és a müvészi kör adatokkal, információkkal látja el az írót, aki egyedül, a saját kutatómunka és értelmezési folyamat végére alkotja meg a szövegkönyvet. Ez az alkotói folyamat hasonlít leginkább egy klasszikus drámaírói tevékenységhez. Az improvizáció, az együttalkotás és közös értelmezés a próbafolyamat során szintén teret kaphat. A (3) vegyes megközelítés bizonyos elemeiben ötvözi a két első munkamódszert, és a saját folyamatainkra reflektálva mi ennek szellemében végeztük a közös munkát. A munkafázisok a következők voltak:

I.) A kutatók, színészek és az író/színész/rendező a közös találkozókon megismerkednek, és elmélyülnek az adatokban, jegyzetekben, megosztják egymással a témával kapcsolatos ismereteiket, tapasztalataikat, véleményüket.

II.) Improvizációs munka - csakúgy, mint a kollektív megközelítés esetében az esetünkben író/rendező/színész vezetésével zajlik a közös értelmezés és tervezés munka jelenetről jelenetre.

III.) Végül az író összedolgozza a jeleneteket, szövegkönyvet készít, mely a későbbi próbák és előadások során is improvizációs alapként szolgál. 
Kutatóként kísérve a folyamatot, ebben a bevonásra és közös alkotásra meghívó és ösztönző munka végére mi is kettős szerepbe kerültünk. Nemcsak kutatói, hanem a kutatás eredményeit feldolgozó színházi kalandjáték szereplőivé is váltunk, mintegy hidat építve a valóság és a fikció között.

\section{KÖVETKEZTETÉSEK}

Projektünk tapasztalatai azt támasztják alá, hogy müvészet és tudomány természetes szövetségesei lehetnek egymásnak a posztnormál tudományfelfogás keretei között. A müvészet nyelve sokkal szélesebb köröket érhet el, és - amenynyiben egy kutatás nem csak egyoldalú közlésként tervez vele - a független nézők reakciói és véleményei visszaforgathatók a kutatásba, újabb tudásbirtokosokat vonva be abba. Mégpedig ez oly módon történik meg, hogy mindezt nem a tudomány magasztos nyelvezetén - a kutatás alanyaiként -, eleve egy hatalmi egyenlőtlenséget sugárzó környezetben teszi, hanem teljes informáltságot és bölcsességet feltételezve. A müvészet-tudomány együttmüködésből már azonban eleve adódik, hogy sokféle tudás egyszerre hozza létre a megértést, gazdagítva annak mélységét. A folyamat során mi is számtalanszor szembesültünk azzal, hogy a müvészek a közgazdaságtan területén laikusként mozogva hogyan tártak fel olyan összefüggéseket, amelyek segítették magának a kutatónak a megértését is. Így a sokféle tudás becsatornázásának követelménye, - amely oly fontos kitétele a posztnormál tudomány követésének - már eleve megvalósul.

Az ilyen típusú együttmüködések elterjedése nyilvánvalóan hozzájárulna mind a tudomány, mind a müvészet átalakulásához. Azonban az fontos lehet, hogy a posztnormál tudomány filozófiájához hüen az ilyen együttmüködések csak akkor járulnak igazán hozzá a világban létező makacs problémák megoldásához, ha abban egymástól független, autonóm gondolkodású és működésü felek vesznek részt, akik nyíltan vállalhatják véleményüket és érdekeiket. Így érdemes azt is figyelembe venni, hogy milyen körülmények vezethetnek ahhoz, hogy például a tudomány ne megrendelöként lépjen fel ilyen helyzetekben, vagy a müvészetek képviselői - a mi esetünkben egy független színházi társaság - ne kényszerből, hanem missziójával összhangban, szabad elhatározásukból legyenek részesei egy ilyen projektnek. Megrendelésre, valaminek az alátámasztására nem jöhet létre olyan együttműködés, amely a posztnormál felfogáson belül tudományosan megalapozottnak tekinthető. Ugyanez igaz abban a helyzetben, amikor a néző véleménye is hat a kutatásra. Azoknak a körülményeknek a megteremtése, hogy a néző függetlenül, befolyásmentesen nyilvánulhasson meg, szintén része a megközelítésnek. Ha mindezek adottak, akkor az ilyen interakciókból tovább mélyíthető bármely téma megértése. 


\section{KÖSZÖNETNYILVÁNÍTÁS}

A szerzők köszönetüket szeretnék kifejezni az eredeti kutatás létrejöttében szerepet játszó Civil Licit Alapítvány munkatársainak (Keresztszeghy István, Nemes Szilárd, Kováts Dóra), a Magyarországi Üzleti Tanács a Fenntartható Fejlődésért (BCSDH) munkatársainak (Fertetics Mandy és Márta Irén), valamint a backcasting mühely összes résztvevőjének, hogy idejüket és erőfeszítéseiket önként a kutatásnak szentelték, és megosztották velünk rendkívül értékes gondolataikat. Szintén szeretnénk köszönetet mondani Valcz Péternek a kalandjáték rendezéséért és abban játszott alakításáért, Szabó Rékának az együttműködésért, valamint a Tünet Együttes színészeinek (Czakó Máté, Gőz István, Szász Dániel, Papp Éva) és háttérstábjának (Kápolnai Katalin, Sáfrány Anna Viola) a támogatásért. Az első szerző munkáját a PD128624 számú projekt a Nemzeti Kutatási Fejlesztési és Innovációs Alapból biztosított támogatással, a Posztdoktori Kiválósági pályázati program finanszírozásában támogatja.

\section{IRODALOM}

Belliveau, G. - Lea, G. W. (eds.) (2016): Research-based Theatre - An Artistic Methodology. Bristol, UK: Intellect, https://www.academia.edu/20700645/Research-Based_Theatre_in_Education

Frame, B. - Brown, J. (2008): Developing Post-Normal Technologies for Sustainability. Ecological Economics, 6, 2, 225-241. DOI: 10.1016/j.ecolecon.2007.11.010, https://www.landcareresearch. co.nz/publications/researchpubs/post_normal_technologies_.pdf

Funtowicz, S. O. - Ravetz, J. R. (1993): Science for the Post-normal Age. Futures, 25, 739-755. https://www.uu.nl/wetfilos/wetfil10/sprekers/Funtowicz_Ravetz_Futures_1993.pdf

Kelemen E. (2016): Tudós és nem tudós szakértők az ökoszisztéma-szolgáltatásokról: párbeszéd a fenntarthatóbb tájhasználat érdekében, Replika, 5, 55-59. http://www.replika.hu/system/files/ archivum/replika_100-07_kelemen_0.pdf

Király G. - Köves A. - Pataki Gy. et al. (2014): Rendszermodellezés és részvétel: egy magyar kísérlet tanulságai. Szociológiai Szemle, 24, 2, 90-115. http://szociologia.hu/dynamic/kiraly_et_all.pdf

Köves A. (2016): Vissza a jövőböl: Komplex, rendszerszintű problémákra adott lehetséges válaszok kutatása a backcasting módszer segítségével. Prosperitas, III, 2, 17-36. http://publikaciotar.repozitorium.uni-bge.hu/1079/1/Koves-Alexandra.pdf

Köves A. - Gáspár J. - Matolay R. (2019): Kutatási jelentés a „,Milyen lesz a jövő vállalata? Avagy fenntarthatóan és felelösen müködö gazdasági szereplök 2050-ben” backcasting workshop eredményeiröl, Corvinus Kutatások

Lea, G. W. (2012): A kutatásalapú színházi munka megközelítései. In: Varga A. (szerk.) (2016): Színház és Pedagógia X.: A kutatásalapú színház. Budapest: ParForum Káva (Approaches to Developing Research-based Theatre. Youth Theatre Journal, 2012) https://bit.ly/2Evlmxz

Leavy, P. (2015): Method Meets Art. New York-London: The Guilford Press

Málovics Gy. (2012): Környezetvédelem vagy társadalmi igazságosság - A környezeti igazságosság koncepciójának értelmezési lehetőségei és hazai jelentősége. Kovász, Tavasz-tél, 3-31. http://kovasz.uni-corvinus.hu/2012/malovics.pdf 
Matolay R. (2013): Agrár-bitoechnológiai társaságok legitimációs stratégiái. PhD-disszertáció. Budapest: Budapesti Corvinus Egyetem, http://phd.lib.uni-corvinus.hu/736/

Pataki Gy. - Takács-Sánta A. (2004): A közgazdaságtan: a társadalomtudományok királynője? In: Pataki Gy. - Takács-Sánta A. (szerk.): Természet és gazdaság. Ökológiai Közgazdaságtan Szöveggyüjtemény. Budapest: Typotex Kiadó, 7-25. https://www.regikonyvek.hu/kiadas/termeszet-es-gazdasag-2005-typotex-kiado

Ravetz J. (2015): Az elővigyázatosság posztnormál tudománya. Kovász, Tavasz-tél, 3-18. (The Post-normal Science of Precaution.) Futures, 2004, 36, 3, 347-357. http://epa.oszk. hu/00700/00721/00026/pdf/EPA00721_kovasz_2015_01-04_003-018.pdf

Réti M. - Varga Gy. (2008): Új tendenciák a fenntarthatóságra nevelésben. Pedagógiai Szemle, 10, https://folyoiratok.ofi.hu/uj-pedagogiai-szemle/uj-tendenciak-a-fenntarthatosagra-nevelesben

Rittel, H. - Weber, M. (1973): Dilemmas in a General Theory of Planning. Policy Sciences, 4, 155-169. http://urbanpolicy.net/wp-content/uploads/2012/11/Rittel+Webber_1973_PolicySciences4-2.pdf

Robinson, J. (2003): Future Subjunctive: Backcasting as Social Learning. Futures, 35, 839-856. DOI: 10.1016/S0016-3287(03)00039-9, https://www.researchgate.net/publication/223711174 Future_Subjunctive_Backcasting_as_Social_Learning

Røpke I. (2004): The Early History of Modern Ecological Economics. Ecological Economics, 50, 293-314. https://www.researchgate.net/publication/222564668_The_Early_History_of_Modern_Ecological_Economics

Sekulova, F. - Kallis, G. - Rodríguez-Labajos, B. et al. (2013): Degrowth: From Theory to Practice. Journal of Cleaner Production, 38, 1-6. DOI: 10.1016/j.jclepro.2012.06.022, https://www. academia.edu/14823445/Degrowth_from_theory_to_practice

Shapiro, M. (1988): Introduction: Judicial Selection and the Design of Clumsy Institutions. Southern California Law Review, 61, 1555-1563. 